\title{
Prevalensi Otitis Media Akut di RS Islam Siti Rahmah Padang Tahun 2017
}

\author{
Yuniarti, $\mathrm{D}^{1}$, Asman, $\mathrm{ST}^{2}$, Fitriyasti, $\mathrm{B}^{3}$ \\ ${ }^{1}$ Mahasiswa Fakultas Kedokteran Univeristas Baiturrahmah \\ Email : delpiyuniarti@gmail.com \\ ${ }^{2}$ Bagian Ilmu Penyakit Telinga, Hidung, Tenggorokan dan Kepala Leher, Fakultas Kedokteran Univeristas \\ Baiturrahmah, Padang, Indonesia. \\ ${ }^{3}$ Bagian Ilmu Biokimia, Fakultas Kedokteran, Universitas Baiturrahmah, Padang, Indonesia
}

\begin{abstract}
Abstrak
Latar Belakang: Otitis Media Akut (OMA) adalah peradangan akut pada telinga tengah yang berlangsung kurang dari tiga minggu. Otitis Media Akut merupakan penyakit infeksi yang umum pada usia dini dan merupakan alasan umum untuk berobat. Penyakit infeksi ini dapat disebakan oleh banyak faktor. Tujuan: Penelitian ini bertujuan untuk mengetahui Prevalensi otitis media akut di Rumah Sakit Islam Siti Rahmah Padang. Metode Jenis penelitian ini adalah deskriptif retrospektif dengan menggunakan data sekunder berupa rekam medis. Penelitian dilakukan dari bulan Juli 2018 - Januari 2019 di bagian THT Rumah Sakit Islam Siti Rahmah Padang. Hasil:Subjek penelitian berjumlah 63 pasien Otitis Media Akut. Penelitian ini melaporkan distribusi frekuensi dari karakteristik penelitian seperti usia, jenis kelamin, stadium, dan telinga yang terinfeksi. Hasil Penelitian ini melaporkan prevalensi dari 63 pasien dengan Otitis Media Akut. Berdasarkan usia, terbanyak diderita pada usia balita sebanyak 12 kasus $(19 \%)$. Berdasarkan jenis kelamin, terbanyak diderita oleh perempuan sebanyak 35 kasus (55.6\%). Berdasarkan stadium, kasus terbanyak pada stadium hiperemis 31 kasus (49.2\%). Berdasarkan telinga yang terinfeksi, kasus terbanyak terjadi pada unilateral sebanyak 61 kasus (96.8\%). Kesimpulan: Pada penelitian ini didapatkan prevalensi otitis media akut pada pasien yang berusia 0-5 tahun, jenis kelamin perempuan, stadium hiperemis dan telinga terinfeksi pada unilateral.
\end{abstract}

Katakunci - Otitis media, hiperemis, unilateral

\begin{abstract}
Background:Acute Otitis Media (OMA) is an acute inflammation of the middle ear that lasts less than three weeks. OMA is a common infectious disease at an early age and is a common reason for treatment. This infectious disease can be caused by many factors. Objective: This study aims to determine the prevalence of acute otitis media at Siti Rahmah Islamic Hospital in Padang. Method This type of research is descriptive retrospective using secondary data in the form of medical records. The study was conducted from July 2018 January 2019 in the ENT section of the Siti Rahmah Islamic Hospital in Padang. The research subjects were 63 patients with Acute Otitis Media. This study reports the frequency distribution of research characteristics such as age, sex, stage, and infected ears. Result of this study report the prevalence of 63 patients with Acute Otitis Media. Based on age, the majority suffered at the age of five as many as 12 cases (19\%). Based on gender, the majority of women suffered 35 cases $(55.6 \%)$. Based on the stage, the most cases were at the stage of hyperemia 31 cases (49.2\%). Based on the infected ear, the most cases were unilateral in 61 cases (96.8\%). Conclusion: In this study the prevalence of acute otitis media in patients aged 0-5 years, female, hyperemic stage and unilateral infected ears were found.
\end{abstract}

Keywords-Otitis media, hyperemia, unilateral 


\section{Pendahuluan}

Otitis media akut seringkali terjadi pada anak-anak. Beberapa negara maju menjelaskan bahwa otitis media akut merupakan infeksi yang umum pada usia dini dan merupakan alasan umum untuk berobat. Prevalensi otitis media akut di setiap negara berbeda-beda, namun biasanya berada pada kisaran 2,3\% - $20 \%{ }^{1}$ Salah satu laporan Active Bacterial Core Surveilance (ABCs) dari Center for Disease Control and Prevention (CDC) menunjukkan kasus OMA terjadi sebanyak enam juta kasus per tahun. Maropol, dkk juga mendapati OMA menyebabkan 45-62\% indikasi pemberian antibiotik pada anak-anak di Amerika Serikat. $^{2}$

Prevalensi tertinggi OMA di dunia terjadi di Afrika Barat dan Tengah (43,37\%), Amerika Selatan (4,25\%), Eropa Timur (3,96\%), Asia Timur $(3,93 \%)$, Asia Pasifik $(3,75 \%)$, dan Eropa Tengah (3,64\%). Di Inggris, sebanyak $30 \%$ anak - anak mengunjungi dokter anak setiap tahunnya karena OMA. Di Amerika Serikat, sekitar 20 juta anak - anak menderita OMA setiap tahunnya. Di Asia Tenggara, Indonesia termasuk keempat negara dengan prevalensi gangguan telinga tertinggi $(4,6 \%)$. Tiga negara lainnya adalah Sri Lanka $(8,8 \%)$, Myanmar $(8,4 \%)$ dan India $(6,3 \%)^{3}$

Di Indonesia sendiri belum ada data baku tentang prevalensi otitis media akut. Berdasarkan survei kesehatan indra pendengaran tahun 1993-1996 pada 7 provinsi di Indonesia didapatkan prevalensi penyakit telinga tengah populasi segala umur di Indonesia sebesar 3,9\%. ${ }^{4}$ Penelitian OMA di Rumah Sakit Immanuel Bandung tahun 2013 di dapatkan penderita OMA terbanyak pada kelompok toddles $(40,4 \%)$, anak lakilaki (52\%), anak-anak dengan pekerjaan orang tua ibu rumah tangga $(48,1 \%)$. Didapatkan bahwa dari 52 kasus OMA di
Rumah Sakit Immanuel Bandung tahun 2013 didapatkan 43 kasus dengan faktor risiko ISPA yaitu sebanyak $82,7 \%{ }^{4}$

Penelitian OMA juga dilakukan di Poli THTKL RSUP Dr. M. Djamil Padang tahun 2015 di dapatkkan 192 pasien OMA dengan kejadian tertinggi, pada musim hujan $(65,6 \%)$, usia 6-12 tahu $(30,7 \%)$, laki-laki $(56,3 \%)$, keluhan otalgia $(57,3 \%)$, stadium hiperemis (unilateral) $(46,7 \%)$ dan hiperemis-hiperemis (bilateral, sinistradextra) $(36,8 \%)$, serta riwayat infeksi saluran nafas atas $(85,9 \%)^{5}$

Otitis media terbagi atas; (1) otitis media supuratif yaitu otitis media supuratif akut atau otitis media akut dan otitis media supuratif kronik. (2) otitis media non supuratif atau otitis media serosa yaitu otitis media serosa akut (barotrauma atau aerotitis) dan otitis media serosa kronik (glue ear). (3) otitis media spesifik seperti otitis media sifilitika atau otitis media tuberkulosa, dan (4) otitis media adhesiva. Penyebab otitis media yaitu bakteri aerob seperti Streptococus aures, Pneumokok, Hemolyticus influenza, Escherichia coli, Streptococus anhemolitikus, Streptococus hemolyticus, Proteus vulgaris dan Pseudomonas aeruginosa. ${ }^{6,7}$

Faktor resiko yang paling berkaitan dengan OMA ialah usia. Kasus OMA secara umum paling sering terjadi pada anak-anak. Faktor anatomis, dimana pada fase perkembangan telinga tengah saat usia anak-anak, tuba eustachius memang memiliki posisi yang lebih horizontal dengan drainase yang minimal dibandingkan dengan usia lebih dewasa menyebabkan terjadinya OMA. Hal inilah yang membuat kecenderungan terjadinya OMA pada usia anak-anak lebih besar dan lebih ekstrim dibandingkan usia dewasa. $^{8}$

Otitis Media Akut dihasilkan saat patogen yang berasal dari nasofaring bertemu dengan 


\begin{tabular}{|c|c|c|c|}
\hline \multicolumn{2}{|c|}{$\begin{array}{l}\text { TABEL } 1 \text { DISTRIBUSI } \\
\text { BERDASARKAN USIA }\end{array}$} & FREKUESI & OMA \\
\hline Usia & $\mathbf{n}$ & $\%$ & \\
\hline Balita & 12 & 19.0 & \\
\hline Anak-anak & 9 & 14.3 & \\
\hline Remaja Awal & 1 & 1.6 & \\
\hline Remaja Akhir & 11 & 17.5 & \\
\hline Dewasa Awal & 9 & 14.3 & \\
\hline Dewasa Akhir & 10 & 15.9 & \\
\hline Lansia Awal & 5 & 7.9 & \\
\hline Lansia Akhir & 6 & 9.5 & \\
\hline Jumlah & 63 & 100.0 & \\
\hline
\end{tabular}

cairan inflamasi yang terkumpul di telinga tengah. Poliferasi patogen pada ruang ini akan berujung pada timbulnya tanda dan gejala tipikal dari infeksi akut telinga tengah. Diagnosis untuk OMA memerlukan adanya cairan di telinga tengah ditandai dengan imobilitas membran timpani. ${ }^{9}$

Survey awal yang dilakukan di RSI Siti Rahmah Padang, didapatkan data pasien berjumlah 133 orang. Berdasarkan data yang diperoleh dan belum adanya data penelitian mengenai prevalensi otitis media akut di Rumah Sakit Islam Siti Rahmah. Untuk itu peneliti tertarik untuk melakukan penelitian mengenai prevalensi otitis media akut di RSI Siti Rahmah Padang tahun 2017.

\section{Metode Penelitian}

Penelitian ini merupakan penelitian deskriptif retrospektif yang menggunakan data sekunder yang berasal dari rekam medis pasien otitis media akut di Rumah Sakit Islam Siti Rahmah Padang. Teknik pengambilan sampel adalah simple random sampling. Besar sampel minimal yang akan diambil pada penelitian adalah sebanyak 63 orang. Pengolahan data dilakukan dengan menggunakan program SPSS dengan analisa data yang dilakukan yaitu analisa univariat untuk memperoleh gambaran masing-masing variabel.

\section{HASIL}

Berdasarkan tabel 1 dapat dilihat bahwa frekuensi tertinggi kejadian OMA berdasarkan umur terjadi pada kelompok balita, yaitu 12 kasus (19.0\%).

\begin{tabular}{llll} 
TABEL $\quad 2$ & DISTRIBUSI & FREKUESI & OMA \\
BERDASARKAN JENIS KELAMIN & \\
\hline \multicolumn{2}{l}{ Jenis Kelamin } & $\mathbf{n}$ & $\mathbf{\%}$ \\
\hline Laki-laki & 28 & 44.4 \\
Perempuan & 35 & 55.6 \\
Jumlah & 63 & 100.0 \\
\hline
\end{tabular}

Berdasarkan tabel 2 dapat dilihat bahwa frekuensi tertinggi kejadian OMA berdasarkan jenis kelamin terjadi pada kelompok perempuan, yaitu 35 kasus $(55.6 \%)$.

\begin{tabular}{|c|c|c|c|}
\hline $\begin{array}{l}\text { TABEL } \\
\text { BERDASAR }\end{array}$ & & KUESI & OMA \\
\hline Stadium & $\mathbf{n}$ & $\%$ & \\
\hline Oklusi & 4 & 6.3 & \\
\hline Hiperemis & 31 & 49.2 & \\
\hline Perforasi & 27 & 42.9 & \\
\hline Supuratif & 1 & 1.6 & \\
\hline Jumlah & 63 & 100.0 & \\
\hline
\end{tabular}

Berdasarkan tabel 3 dapat dilihat bahwa frekuensi tertinggi kejadian OMA berdasarkan stadium terjadi pada stadium hiperemis, yaitu 31 kasus (49.2\%).

\begin{tabular}{|c|c|c|}
\hline \multicolumn{3}{|c|}{$\begin{array}{lccc}\text { TABEL } & 4 & \text { DISTRIBUSI } & \text { FREKUE } \\
\text { BERDASARKAN TELINGA TERINFEKSI }\end{array}$} \\
\hline Telinga Terinfeksi & $\mathbf{n}$ & $\%$ \\
\hline Unilateral & 61 & 96.8 \\
\hline Bilateral & 2 & 3.2 \\
\hline Jumlah & 63 & 100.0 \\
\hline
\end{tabular}

Berdasarkan tabel 4 dapat dilihat bahwa frekuensi kejadian OMA berdasarkan telinga yang terinfeksi terjadi pada unilateral, yaitu 61 kasus $(96.8 \%)$.

Penelitian dilakukan terhadap 19 orang pasien tersangka efusi pleura tuberkulosis (EPTB) yang mengirimkan sampel cairan 
pleura ke laboratorium RSUP Dr. M. Jamil Padang dari bulan Juli 2016 sampai Januari 2017.

\section{Pembahasan}

Otitis Media Akut (OMA) pada penelitian ini lebih banyak diderita oleh pasien usia balita dengan rentang usia 0-5 tahun (19\%). Penelitian sebelumnya oleh Umar et al. terhadap 1565 orang di Kodya Jakarta Timur mendapatkan bahwa usia merupakan salah satu faktor resiko yang berkaitan dengan prevalensi kejadian Otitis Media ${ }^{10}$. Usia balita merupakan usia yang paling berpotensi untuk mengalami Otitis Media Akut, dan memiliki kecendrungan 2,46 kali lebih besar dibandingkan usia lainnya. ${ }^{11}$ Bentuk anatomi pada anak-anak juga berpengaruh dalam kejadian OMA, karena tuba eustachius pada anak-anak memiliki ukuran bentuk yang lebih pendek, serta belum matang. ${ }^{12}$

Otitis Media Akut lebih banyak diderita oleh perempuan $(55,6 \%)$. Berbeda dengan penelitian yang dilakukan Samuel (2014) terhadap pasien rawat inap di RS Imanuel, Bandung dan penelitian Lestari (2010) yang menemukan bahwa laki-laki merupakan jenis kelamin terbanyak menderita Otitis Media Akut. ${ }^{13,14}$ Hal ini diduga berkaitan dengan pneumatisasi mastoid yang lebih kecil pada laki-laki, pajanan polusi serta trauma yang lebih sering terjadi pada laki-laki. Terdapat banyak factor risiko yang dapat mempengaruhi kejadian OMA, diantaranya adalah usia, daycare attendance, breastfeeding, terpapar asap rokok, penggunaan antibiotik, serangan otitis sebelumnya, dan terdapat patologis lain yang mendasari. $^{15}$

Penelitian-penelitian terbaru juga melaporkan bahwa kelainan anomali kraniofasial seperti cleft palate dan trisomy 21 meningkatkan risiko kelainan pada telinga tengah karena terganggunya saluran tuba. Sedangkan kelainan atopic seperti rhinitis alergi dan asma juga merupakan predictor kuat untuk terjadinya OMA, karena peningkatkan kecenderungan untuk terjadinya infeksi pneumococcal. Pada penelitian ini tidak dinilai faktor risiko lain pada pasien OMA. Mekanisme pasti yang dapat menjelaskan bahwa jenis kelamin merupakan faktor risiko terhadap OMA sampai saat ini belum ada. ${ }^{16}$

Stadium hiperemis merupakan stadium terbanyak yang ditemukan pada penelitian ini $(39,2 \%)$. Secara umum, pada stadium ini sangat mudah untuk dikenali, karena gejala klinis yang muncul pada stadium ini cukup jelas. Gejala klinis pada OMA secara umum seperti otalgia, rasa tidak nyaman pada telinga, demam, dan iritabilitas merupakan gejala yang sangat dikeluhkan pada stadium ini, sedangkan pada stadium lain keluhan ini sudah mulai berkurang. ${ }^{17}$

Stadium ini merupakan tanda infeksi bakteri yang menyebabkan pasien mengeluhkan otalgia, telinga rasa penuh dan demam. Pendengaran mungkin masih normal atau terjadi gangguan ringan, tergantung dari cepatnya proses hiperemis. Hal ini terjadi karena terdapat tekanan udara yang meningkat di kavum timpani. ${ }^{18,19}$

Berdasarkan penelitian ini kejadian Otitis Media Akut (OMA) yang terbanyak adalah kasus OMA unilateral, yaitu 61 kasus $(96,8 \%)$ dan hanya 2 kasus $(3,2 \%)$ dengan OMA bilateral. ${ }^{20}$ Penelitian Leibovits et al. (2007) melaporkan hasil penelitian yang berbeda, penelitian beliau melaporkan kasus OMA bilateral sebanyak 623 kasus dan 403 kasus untuk OMA unilateral. ${ }^{21}$

Temuan penelitian melaporkan bahwa kejadian, durasi, dan keparahan gejala tidak berbeda antara OMA bilateral dan unilateral. Kecuali gejala demam, karena anak dengan OMA bilateral lebih sering demam, dan demam dengan suhu yang lebih tinggi dibandingkan dengan OMA unilateral. ${ }^{20}$ 
Temuan penelitian lainnya menyimpulkan bahwa keterlibatan telinga bilateral pada OMA sering terjadi pada anak-anak terutama pada usia 6-8 bulan, non typable $H$. influenza meruapkan etiologi tersering untuk OMA bilateral, dan gambaran klinis OMA bilateral sering lebih berat dibandingkan dengan OMA unilateral serta peradangan pada membrane timpani yang lebih berat. $^{21,22}$

\section{KeSimpulan Dan SaRan}

Penelitian ini menunjukkan bahwa OMA lebih sering pada usia balita dan perempuan lebih sering menderita OMA. Stadium Hiperemis merupakan stadium yang sering dijumpai pada penelitian ini dengan Telinga unilateral yang paling sering terinfeksi.

\section{Daftar Pustaka}

[1] Deshmukh C. 2014. Acute otitis media in children-treatment options. Pediatrics. 44(3) : 814.

[2] American Academy of Pediatrics. 2004. Subcommittee on Management of Acute Otitis Media. Diagnosis and Management of Acute Otitis Media. Pediatrics. 113(5) : 1451-65.

[3] Samuel S, Kardinan B, Soeng S. 2014. Karakteristik Pasien Rawat Inap Otitis Media Akut di Rumah Sakit Immanuel Bandung Periode Januari-Desember 2013. Bandung: Fakultas Kedokteran Universitas Kristen Maranatha.

[4] Hasil survei kesehatan indera penglihatan dan pendengaran. 2006. Departemen Kesehatan RI Ditjen pembinaan kesehatan masyarakat Direktorat bina upaya kesehatan puskesmas.

[5] Aini PD. 2015. Karakteristik Pasien Otitis Media Akut Pada Anak di Poliklinik THT-KL RSUP Dr. M.Djamil Padang Periode 2010-2014. Padang: Fakultas Kedokteran Universitas Andalas.

[6] Rettig E, Tunkel DE. 2014. Contemporary Concepts in Management of Acute Otitis Media in Children. Am Otolaryngol Clin North. 47(5):651-72.

[7] Nagel P. 2012. Dasar-Dasar Ilmu THT. Edisi ke2. Jakarta: EGC.

[8] Tortora GJ. 2012. Principles of Anatomy and Physiologi 13th edition. United States Of America: John wiley \& Sons. Inc.

[9] Sindunata NA. 2013. Otitis Media Akut. Banten: Fakultas Kedokteran Universitas Pelita Harapan

[10] Umar S. 2013. Prevalensi dan faktor risiko otitis media akut pada anak-anak di Kotamadya Jakarta
Timur. Jakarta: Fakultas Kedoteran Universitas Indonesia.

[11] Dewi NU. 2016. Hubungan Usia Dengan Angka Kejadian Otitis Media Akut Di Rumah Sakit Sanglah Denpasar. Denpasar: Fakultas Kedokteran Universitas Udayana.

[12] Szmuilowicz J. Randall Y. 2018. Infections of the Ear. In Bontempo LJ, Jan S. Ear, Nose, and Throat Emergencies. Philadelphia: ElSevier

[13] Lestari RD. Zulhafis M. Marni. 2016. Distribusi usia dan jenis kelamin pada angka kejadian otitis media akut di Rumah Sakit Umum Daerah Abdul Moeloek Bandar Lampung. Jurnal Ilmu Kedokteran dan Kesehatan; 5 (1).

[14] Samuel S. 2013. Karakteristik pasien rawat inap Otitis Media Akut di Rumah Sakit Immanuel Bandung periode Januari-Desember 2013. Skripsi. Universitas Kristen Maranatha. Bandung.

[15] Ramakrishnan K, Sparks R a, Berryhill WE. 2007. Diagnosis and Treatment of Otitis Media. Am Fam Physician.78(1 ):30.

[16] Coticchia JM, Chen M, Sachdeva L, Mutchnick S. 2013. New paradigms in the pathogenesis of otitis media in children. Pediatr. 1:52.

[17] McWilliams CJ, Goldman RD. 2011. Update on acute otitis media in children younger than 2 years of age. Canadian Family Physician;57;1283-5.

[18] Munilson J, Edward Y. 2013. Penatalaksanaan Otitis Media Akut. Padang: Penatalaksanaan Otitis Media Akut Fakultas Kedokteran Universita Andalas.

[19] Soepatdi E arsyad, Iskandar N, Bashiruddin J, Restuti R dwi. 2012. Buku Ajar Ilmu Kesehatan telinga hidung tenggorok kepala dan leher Edisi Ketujuh. Jakarta: FKUI

[20] Uitti JM, Laine MK, Tahtinen PA, Ruuskanen O, Ruohola A. 2013. Symptoms and Otoscopic Signs in Bilateral and Unilateral Acute Otitis Media. Pediatrics; 131:398-405.

[21] Leibovitz E, Asher E, Piglansky L, Givon-lavi N, Satran R, Raiz S, et al. 2007. Is Bilateral Acute Otitis Media Clinically Different Than Unilateral Acute Otitis Media. Pediatr Infect Dis J 2007;26: 589-92.

[22] McCormick DP, Chandler SM, Chonmaitree T. 2007. Laterality of Acute Otitis Media: Different Clinical and Microbiologic Characteristics. Pediatr Infect Dis J 2007;26: 58 